\title{
“MAS, AFINAL, O QUE É LIBERDADE?”: O ESPETÁCULO LIBERDADE LIBERDADE (1965) E A RESISTÊNCIA CULTURAL AO REGIME MILITAR
}

Mariana Rodrigues Rosell ${ }^{1}$

RESUMO: O presente artigo é resultado de pesquisa de Iniciação Científica realizada pela autora com financiamento CNPq entre 2011 e 2012. Trabalhamos a partir da tese de que a resistência civil ao regime militar brasileiro se deu em várias frentes e de diversas formas. Assim, baseamo-nos na hipótese de que há elementos na peça Liberdade Liberdade que permitem pensá-la na chave do frentismo cultural, forma pela qual o Partido Comunista optou na resistência ao regime militar. Identificamos alguns pontos na construção do texto e no conjunto da encenação que colaboram para pensar Liberdade Liberdade como uma precursora da resistência cultural aliancista empreendida pelo PCB e por parte da ala liberal.

Palavras-chave: Teatro Brasileiro; Regime Militar; Resistência Cultural; Grupo Opinião, Liberdade Liberdade;

Em 1965 foi encenada a primeira montagem de Liberdade Liberdade, produzida pelos dois grupos teatrais brasileiros mais representativos à época, Opinião e Teatro de Arena de São Paulo. Nesse momento, o Brasil, já sob o regime militar, assistia a um paulatino cerceamento da liberdade. Ainda que somente em 1968 as artes fossem fortemente atingidas pela censura e o AI-5 trouxesse o fim das liberdades individuais, a discussão cujo tema principal era a liberdade já estava dada. Como se verá no decorrer deste texto, a peça em

${ }^{1}$ Aluna de graduação em História ( $9^{\circ}$ semestre $-5^{\circ}$ ano) da Universidade de São Paulo (DH/FFLCH/USP). Orientanda do Prof. Dr. Marcos Napolitano. Lattes: http://lattes.cnpq.br/8056929819718959. 
Cadernos de Clio, Curitiba, n. ${ }^{\circ}$ 4, 2013

questão desempenhou papel fundamental no primeiro movimento de resistência cultural ao regime.

A pesquisa consistiu em analisar o conjunto da peça na intenção de observar elementos que pudessem mostrar sua inserção num contexto aliancista de resistência cultural ao regime militar, posto em prática pelo Partido Comunista Brasileiro e uma parte da ala liberal. Assim, o estudo sobre Liberdade Liberdade baseou-se na abordagem historiográfica revisionista da resistência aos governos militares para pensar essa peça como importante manifestação cultural do aliancismo que se estabeleceria algum tempo depois de sua estreia, ainda nos primeiros anos após o golpe.

\section{Resistência civil ao regime militar e o papel do Grupo Opinião}

Ao tratarmos da resistência civil ao regime militar é preciso que tenhamos em mente a necessidade de matizar a construção da memória hegemônica acerca dela. Construiu-se, ao longo dos anos, a ideia de que os opositores civis aos militares resistiram como um bloco uno e com os mesmos meios e fins. O golpe de 1964 apresentou novos obstáculos ao projeto de atuação de uma frente única de esquerda e, por isso, o entendimento de uma resistência homogênea precisa ser relativizado, pois esta foi, na verdade, bastante heterogênea. Assim, é possível e necessário que se pense a atuação da resistência ao regime em chaves diversas. Trabalhando na chave da resistência democrática cultural, podemos identificar quatro grupos distintos: 1) comunistas, 2) liberais, 3) contracultura e 4) nova esquerda (NAPOLITANO, 2011). Cabe, para este trabalho, nos atermos aos dois primeiros segmentos, localizando Liberdade Liberdade na intersecção de sua resistência e conside- 
rando que o público desse teatro foi, em sua quase totalidade, de classe mé$\operatorname{dia}^{2}$.

O golpe de 1964 não se deu somente pela atuação das forças militares. Sabe-se que grande parte da sociedade civil não só o apoiou como também ajudou, das mais diversas formas, a sustentar o regime por ele implantado. Daí grande parte da historiografia sobre o período ter passado a discutir recentemente o caráter do golpe - alguns também do próprio regime -, considerando-o civil-militar. Um episódio bastante significativo nesse sentido é a "Marcha da família com Deus pela liberdade"” , que não foi o único, mas acabou por se tornar o mais conhecido evento organizado por civis em defesa de propósitos que os militares também defenderiam ao chegarem ao poder. Além disso, parte da ala liberal, entenda-se aqui, os políticos, apoiara o golpe intencionando, na verdade, aproximar-se do governo quando os militares devolvessem o poder às mãos dos civis. Esse foi o caso, por exemplo, de

${ }^{2}$ A busca pela ampliação do público teatral para além da classe média esteve presente em projetos culturais mesmo antes do golpe de 1964. O CPC foi o principal núcleo articulador desse projeto e, em grande parte, há uma continuidade do mesmo na atuação do Grupo Opinião. No entanto, ainda que a tenha intensificado, o golpe introduziu novas dificuldades à realização desse projeto em virtude da "vigilância do regime autoritário”, por exemplo (NAPOLITANO, 2001). Vigilância esta que também notava que o público de Liberdade Liberdade era composto pela classe média, o que, às vezes, favorecia sua liberação. Em um laudo censório de 1969 (constante do processo de censura da peça, disponível no Arquino Nacional do Distrito Federal), consta que a encenação se dirigia a "uma plateia adulta e bem formada [...] a qual é selecionada pelo próprio ingresso à sala do espetáculo (custo e ambiente), fazendo com que não atinja a massa menos instruída."

${ }^{3}$ Apesar de o nome sugerir, não se trata de uma marcha especificamente, mas sim de um conjunto de manifestações organizadas pelos setores civis (políticos, damas da alta sociedade, representantes da Igreja) na quinzena que antecedeu o golpe de 31 de março de 1964. 
Cadernos de Clio, Curitiba, n. ${ }^{\circ}$ 4, 2013

Carlos Lacerda. A não concretização desse projeto foi um dos elementos que levaram ao rompimento do pacto de apoio entre parte da ala liberal e os governantes militares.

A imprensa, principal voz dessa ala, desempenhou papel crucial nos primeiros dias após o golpe e nos primeiros anos do regime, apoiando os militares através da publicação, sobretudo, de editoriais favoráveis a eles. O processo que levou ao esquecimento desse apoio e construiu uma imagem da imprensa como grande vítima da censura e paladina da resistência se deu por inúmeros fatores relacionados à constituição da memória hegemônica brasileira, que pauta os discursos não acadêmicos e, algumas vezes, é respaldada pela própria historiografia.

O que se intenta apontar aqui é que muito do que se fala, sobretudo fora do ambiente acadêmico, sobre o regime militar brasileiro baseia-se, principalmente, nas memórias dos coetâneos do período e isso ocorre por muitos motivos, entre eles, a dificuldade de acesso a documentos. Não cabe, no entanto, tratar disso mais detidamente agora. O importante é ressaltar que, diferentemente do que se costumou pensar, os liberais, principalmente na figura da imprensa e de políticos, foram apoiadores do golpe em nome do restabelecimento de uma ordem (dita) ameaçada, e, em princípio, viam no regime militar instituído a melhor via para atingir seu fim, qual seja, a manutenção de uma ordem democrática.

Quanto às esquerdas, é fundamental ter em mente que o desencadeamento do autoritarismo impulsionaria a fragmentação dos militantes do Partido Comunista, gerando as várias dissidências que ingressariam na luta armada. Assim, paulatinamente, as divergências na forma de enxergar a situação política e a discussão acerca de qual o melhor meio para se enfrentar o regime 
militar, bem como as diferentes propostas para o momento em que o governo ditatorial fosse deposto, fizeram com que a resistência de esquerda se desse de forma heterogênea, manifestando a heterogeneidade intrínseca mesmo ao partido. Daí surgirem as tantas organizações armadas, de certa forma, em oposição à esquerda que permaneceu fiel ao PCB, chamada tradicional, e defendeu as determinações da Resolução de Maio de $1965^{4}$, que definiu a resistência democrática através do frentismo cultural como principal linha de atuação do partido.

Em relação à classe artística, é necessário apontar que, em sua grande maioria, ela custou a crer que o regime imposto pelo golpe seria duradouro. Em virtude, sobretudo, da certa liberdade no exercício das artes (até o AI-5), tal grupo - que nunca foi homogêneo - demorou mais de um ano para perceber que os militares se pretendiam perpetuar no governo. Denis de Moraes, na biografia que escreveu sobre Vianinha, diz que:

A crença de que o autoritarismo teria limitado poder de vôo era animada, em círculos da intelectualidade, pela constatação de que o setor menos golpeado pelo regime militar, até ali [inícios de 1965], fora a cultura. (MORAES, 2000: 190)

O Grupo Opinião fora formado por artistas de diversos segmentos advindos dos comitês culturais do CPC - Centro Popular de Cultura -, que havia sido posto na ilegalidade pelos militares após o golpe como meio de cortar

${ }^{4}$ A resolução do Comitê Central do PCB reiterava a definição do partido pela "nova política” (determinada em 1958), optando, portanto, pela "prudência, [...] reorganização dos quadros, [...] acúmulo de forças, [...] unidade das oposições, [...] luta política (ou seja, não armada) contra o regime.” (NAPOLITANO, op. cit.: 30. Grifo nosso.). Ou seja, a partir dela, a fragmentação do PCB intensificou-se, determinando a implementação da luta armada pelos dissidentes, que discordavam dessas determinações. 
definitivamente os vínculos entre a classe artística mobilizada e as classes populares. Uma de suas figuras centrais foi o próprio Vianinha, que, antes de fazer parte dos quadros do CPC, havia integrado também o Teatro de Arena de São Paulo e é um dos principais nomes do teatro político e da esquerda artística brasileiros $^{5}$. A intenção do grupo era a de constituir um foco de resistência pelo viés teatral. Nesse sentido, desempenhou papel crucial: "Grupo carioca que centraliza, nos anos 1960, o teatro de protesto e de resistência...” (ENCICLOPÉDIA ITAÚ CULTURAL DE TEATRO, 2010). Já em 1964 estrearia seu primeiro espetáculo, o famoso show Opinião, que, utilizando uma fórmula parecida com a que seria empregada no ano seguinte em Liberdade Liberdade (texto mesclado a canções), ficaria conhecido como a primeira manifestação de resistência cultural ao regime militar.

O ano de 1965 é um marco na aliança que se deu entre liberais e membros da esquerda tradicional na luta contra o regime militar. Em 27 de outubro desse ano foi editado o Ato Institucional No2 (AI-2) que, entre outras mudanças, extinguia o pluripartidarismo vigente, instituindo o bipartidarismo autoritário entre situação e oposição que permaneceria até 1979. Este ato foi a gota d’água para que os liberais percebessem que o golpe e, posteriormente, o

${ }^{5} \mathrm{O}$ engajamento político de Vianinha e a influência deste na sua dramaturgia foi alvo, ao longo dos anos, tanto de críticas negativas como positivas. Um panorama destas críticas pode ser conferido em PATRIOTA, Rosângela. Vianinha: um dramaturgo no coração de seu tempo. São Paulo: Hucitec, 1999, pp. 93-98. A autora afirma que a prioridade de Vianinha foi "trazer para o palco conflitos inerentes à realidade brasileira e entendendo a arte como instrumento de luta” (p. 98). De todo modo, essa junção entre sua atuação política e sua atuação artística faz de sua obra uma referência fundamental para se entender a atuação da esquerda no contexto de finais dos anos 1950 e 1960 antes do golpe e também da primeira década de regime militar. 
regime que apoiaram não eram de caráter temporário e muito menos democrático. Em sua tese de livre-docência, Marcos Napolitano aponta que

as ilusões oportunistas [dos liberais] logo se perderiam com o Ato Institucional n.2 [...] os militares avisavam [com ele] as lideranças civis sequiosas para chegar ao Palácio do Planalto que eles tinham vindo para ficar. A intervenção "moderadora” e a "ditadura” saneadora, solicitada e autorizada pela direita civil de um sistema político em frangalhos, se afirmava com um projeto estratégico e de longo prazo, buscando meios para institucionalizar-se e permanecer no poder. (NAPOLITANO, op.cit.: 28)

Se o AI-2 ajudaria a intensificar as divergências internas acerca de qual a melhor forma de agir na luta contra a ditadura, em maio de 1965, a resolução da primeira reunião do Comitê Central do Partido Comunista após o golpe de 1964, já daria a orientação aliancista que o partido seguiria dali em diante. Assim, a despeito de todas as divergências existentes entre eles, a conjuntura política a partir de 1965 permitiu (e favoreceu) a aliança entre os comunistas que se mantiveram fieis à orientação do partido e parte dos liberais. Nesse contexto, o Grupo Opinião se uniria ao Teatro de Arena de São Paulo para produzir Liberdade Liberdade, que se tornaria, nesses primeiros anos, a grande manifestação da resistência aliancista ${ }^{6}$.

${ }^{6}$ A resistência aliancista foi empreendia por uma parte da ala e pela esquerda ligada ao PCB. Baseada especialmente na atuação pelas artes e pela cultura, foi posta em prática por políticos, artistas e intelectuais ideologicamente liberais que, se desiludiram com o regime ao perceberem que este não pretendia ser transitório, mas, pelo contrário, buscava se legitimar e garantir a implementação de um projeto contínuo e de longo prazo; e por artistas e intelectuais orientados, sobretudo, pela defesa da via etapista para a realização da revolução brasileira e pela aliança de classes, defendidas 
Uma figura muito importante para essa aliança e para a resistência cultural é o intelectual. Ainda em sua tese, Napolitano desenvolve esse apontamento:

Procuramos articular duas definições acerca do intelectual: uma ampla e sociocultural (criadores e mediadores culturais) e outra mais estrita, fundada na noção de engajamento. As duas noções se articulam, pois o reconhecimento público ou institucional das capacidades e expertises intelectuais (e artísticas) autoriza uma intervenção pública nas questões políticas, sobretudo em épocas marcadas pelo autoritarismo e pela violência política. Neste sentido, a tradição liberal (o intelectual como inteligência reflexiva e arauto da liberdade individual) e a tradição socialista (o intelectual como arauto da liberdade pública e crítico do sistema) podem se entrecruzar em determinadas circunstâncias históricas. (Idem, ibidem: 9 e 10).

Ou seja, o intelectual foi a figura chave dessa aliança, na medida em que através dele duas tradições políticas conseguiram articular-se e dialogar em nome da resistência a um inimigo comum: o regime militar brasileiro.

Em Liberdade Liberdade, é Paulo Autran quem exerce esse papel central. Daí sua seguinte afirmação:

Se o público compreendê-las [as palavras do texto], assimilá-las, amálas, teremos lucrado nós, eles, e o País também. Se isso não acontecer a culpa será principalmente minha, mas pelo menos guardarei dentro de mim a consoladora ideia de que tentei. (AUTRAN apud FERNANDES; RANGEL, 1997: 15. Grifo nosso.)

pelo PCB desde 1958, e adeptos ao projeto nacional-popular. Daí que esta atuação seja conhecida como “frentismo cultural”. Cf. NAPOLITANO, 2011. 
Nota-se que Paulo Autran compreende que grande parte da responsabilidade de comunicar ao público o alerta da peça cabia a ele. Como se verá mais adiante, a escolha de Autran se deu já pensando no potencial do ator nesse sentido.

\section{O espetáculo Liberdade Liberdade: impacto na estreia e longevidade da discussão}

Liberdade Liberdade estreou, não por acaso, em 21 de abril de 1965, no Teatro do Shopping Center de Copacabana, Rio de Janeiro, com texto de Millor Fernandes e Flávio Rangel (este também na direção). Com Paulo Autran, Oduvaldo Vianna Filho, Tereza Rachel e Nara Leão no elenco, a peça permaneceu em cartaz por cerca de dois meses e meio. A importância de Liberdade Liberdade na trajetória da resistência cultural ao regime militar instalado com o golpe em 1964 é destacada tanto no contato com as fontes primárias quanto na bibliografia especializada.

As fontes dão conta de que Liberdade Liberdade foi marco importante para o teatro brasileiro, sendo considerada a primeira peça do teatro de protesto. Yan Michalski ${ }^{7}$ publicou em 27 de abril de 1965 no Jornal do Brasil,

${ }^{7}$ Yan Michalski chegou ao Brasil aos 12 anos, fugido da perseguição nazista. Estabeleceu-se no Rio de Janeiro e em 1955 começou sua carreira teatral. Foi responsável pela coluna de teatro do Jornal do Brasil por 19 anos e escreveu muitos trabalhos importantes sobre o tema, como $O$ palco amordaçado (1979) e $O$ teatro sob pressão: uma frente de resistência (1989). Segundo depoimento de Johana Albuquerque, organizadora da Enciclopédia Itaú Cultural de Teatro, Michalski era, além da principal voz da crítica do teatro no Rio de Janeiro, amigo dos artistas envolvidos com a área, para quem era também um consultor. Ela diz que "Yan Michalski, de certo modo, representava a voz unânime a que todos do teatro carioca queriam ouvir.” (ALBUQUERQUE apud ENC. ITAÚ CULTURAL DE TEATRO, 2009). Assim, sua crítica está 
texto cuja ênfase inicial se dava na crítica aos responsáveis pelo Grupo Opinião por não terem se preocupado em limitar a entrada do público à lotação máxima da arena, que acabou, no dia da estreia, com uma superlotação prejudicial ao pleno desenvolvimento da apresentação. O texto publicado no periódico The New York Times, em 25 de abril de 1965, caminha no mesmo sentido, dizendo que "o mais ambicioso dos espetáculos de protesto, transformou-se imediatamente num sucesso de público.” (ONIS, 1965. Tradução nossa.) Nele também se corrobora a informação de superlotação dada por Michalski; “A audiência de trezentas pessoas, que tinha pago o equivalente a um dólar e vinte e cinco centavos por pessoa para se sentar amontoada [...]” (Idem.)

Pelo processo de censura do texto, é possível notar, pelo menos, de 15 a 18 solicitações de liberação de montagem entre 1967-1969 e 1979-1985 . Ou seja, além da montagem do Grupo Opinião que passou por diversas cidades do país, ultrapassando os limites do eixo cultural Rio-São Paulo ${ }^{9}$, o texto de Rangel e Fernandes despertou interesse em grupos das mais diferentes cidades, amadores ou profissionais. Sendo quase todas as solicitações atendidas pelo Serviço de Censura de Diversões Públicas (SCDP), ainda que possa

entre as principais fontes para o estudo do teatro brasileiro, na medida em que constituíram referência não só para o público, mas também para os artistas.

${ }^{8} \mathrm{O}$ número é aproximado em virtude da incompletude na documentação. As dataslimite que abrangem tais solicitações coincidem com períodos de relativa liberdade e flexibilização da censura sobre as artes, em virtude de nuances e divergências dentro da própria instituição militar acerca da melhor forma de conduzir o regime.

${ }^{9}$ A montagem do Grupo Opinião que excursionou pelo país não contou com todo o elenco original. Ao que se pode observar, apenas Paulo Autran participou de encenações fora do Rio de Janeiro. 
ter sido limitada por cortes e restrições etárias, entende-se que a discussão proposta por Liberdade Liberdade difundiu-se Brasil afora.

Sem dúvida que o fato de ter sido produzida por dois dos grupos teatrais mais importantes do Brasil naquele momento colaborou para o sucesso que a peça obteve. Esse momento único do qual Liberdade Liberdade faz parte dá sentido à discussão proposta pelos autores e introduzida pelos atores que, do palco, pretendiam levar o tema a grupos mais diversos de modo a difundir o debate.

O texto é composto por uma seleção de excertos que abrange um longo período, entre os séculos VI a.C. e XX d.C, mostrando como a questão da liberdade está posta nos mais diferentes contextos históricos, independente do regime político ou tipo de governo que se viva, do espaço onde esteja ou o grupo social do qual faça parte. Isso colabora para a compreensão de Liberdade Liberdade para além do momento de sua elaboração, reforçando uma ideia que contraria as proposições dos autores como se verá um pouco adiante no texto. A colagem, prática já recorrente à época, sobretudo nos Estados Unidos, foi constituída por excertos retirados de poemas, livros, discursos, peças de teatro, etc. abrangendo espaços também diversos: Grécia, Alemanha, França, Inglaterra, Espanha, EUA, além do Brasil e da União Soviética, os quais foram acrescentados de trechos escritos por Millôr Fernandes especialmente para a peça. Outro importante elemento no conjunto do espetáculo era a canção popular.

A relação do texto com o repertório da peça mostrou-se bastante intrínseca. Luiz Giani, em sua dissertação de mestrado, diz que "todas as canções do repertório compõem, de forma sincrônica e entrelaçada com a narração, a ideia principal do espetáculo” (p. 284). As canções escolhidas funcionaram 
como uma espécie de linha, costurando os assuntos a serem discutidos pela peça. A relação é tão fundamental que a crítica da época chegou a questionar a natureza de Liberdade Liberdade; se esta se tratava de uma peça teatral, de um show ou de um musical ${ }^{10}$. Essa discussão, a princípio, não é essencial para as questões desse trabalho; por isso, ressalto apenas que as canções desempenharam papel fundamental na produção do significado de Liberdade Liberdade.

Depoimentos dos envolvidos na peça à época sustentam que ela era produto desse contexto, tendo como principal objetivo alertar o público da situação que se vivia no país. Na edição do texto em livro, lançada já em 1965 pela Editora Civilização Brasileira, foram publicados pequenos comentários dos dois autores, nos quais se pode ler:

Tentamos fazer um espetáculo que servisse à hora presente, dominada, no Brasil, por uma mentalidade que, sejam quais sejam as suas qualidades ou boas intenções, é nitidamente borocochô. (FERNANDES apud FERNANDES;RANGEL, op.cit.: 11. Grifo nosso.)

É evidente que existe um motivo principal para este espetáculo no momento em que vive o nosso País. Liberdade Liberdade pretende reclamar, denunciar, protestar - mas sobretudo alertar. (RANGEL apud idem: 13. Grifo nosso.)

A insistência por parte dos autores na ideia de que Liberdade Liberdade seria uma peça datada foi grande, como se pode observar acima. No entanto, sua encenação se prolongou não só durante o regime militar, mas também

${ }^{10}$ WOLFF, Fausto. Liberdade Liberdade. Tribuna da Imprensa, Rio de Janeiro, 24 e 25 abril 1965. 
ao longo das décadas seguintes, como se nota pela observação do processo de censura e pelas remontagens recentes. ${ }^{11}$

\section{Liberdade Liberdade e seu papel na resistência cultural democrática}

Sobre Liberdade Liberdade, ao fazer um balanço de seu conjunto, nota-se que seu discurso é aliancista. Quando pensamos que as primeiras vozes da resistência, sobretudo cultural, provém da ala liberal, não é de se estranhar que assim o seja. Se observarmos bem, os artistas e intelectuais envolvidos com a primeira montagem são, em maioria, liberais. Afora Oduvaldo Vianna Filho, que era ligado ao Partido Comunista, os demais envolvidos não tinham uma orientação política de esquerda. Millôr Fernandes, Tereza Rachel e Paulo Autran vinham de uma trajetória intelectual moderada, ainda que a posição do primeiro quase sempre tenha sido crítica e que seu contato com o teatro político tenha se inciado antes de Liberdade Liberdade (com tradução de textos de Bertold Brecht). No mesmo sentido, Flávio Rangel vinha de uma trajetória artística ligada ao Teatro Brasileiro de Comédia (TBC) e se engajaria na esquerda - chegando a ser preso no episódio conhecido como “Os oito do Glória”"12 - somente após trabalhar com Liberdade Liberdade.

${ }^{11}$ Em 2005, após quarenta anos de sua primeira encenação, Liberdade Liberdade foi o texto escolhido para estrear o projeto Teatro nas Universidades, relembrando, coincidentemente ou não, um dos espaços em que mais teve sucesso durante o regime militar.

${ }^{12}$ Esse episódio consiste na prisão de oito intelectuais e artistas por realizarem um protesto no Rio de Janeiro em 18 de novembro de 1965, durante a abertura da II Conferência Extraordinária Interamericana da OEA (Organização dos Estados Americanos). A motivação do protesto foi o fato de o regulamento da OEA não permitir a realização dessas atividades em países não democráticos. Como a conferência já estava marcada quando do golpe de 1964, o esforço de Castello Branco se deu no 
Paulo Autran era um artista que, não estando formalmente ligado ao partido, podia transmitir a mensagem deste no espaço público sem o grande risco de perseguição que recaía sobre “cartas marcadas” para o governo, como Vianinha e, um pouco depois, Nara Leão. Além do mais, assim como Tereza Rachel (ainda que no caso dela essa questão tenha menor relevância), Autran era um ator conhecido e já consagrado, bem visto pela sociedade, sendo também esse fato um elemento positivo e agregador ao bom desempenho de público do espetáculo. Vianinha diria:

Flávio sugeriu que se convidasse Paulo Autran para o elenco, o que vinha ao encontro de um dos objetivos centrais do grupo - atrair outros segmentos teatrais para engrossarem a luta antiditatorial. Por seu talento e respeitabilidade artística, Autran reforçaria a unidade geral do pensamento democrático, o mesmo se verificando com as presenças de Tereza Rachel e Nara Leão. (SIQUEIRA, 1995: 192. Grifo nosso.)

Tempos depois, em 2002, Paulo Autran reafirmaria, enfaticamente, sua posição moderada. Ainda que a distância temporal e o recurso à memória possam interferir na visão do ator sobre sua atuação, é interessante observar sua posição. Em entrevista ao programa Roda Viva, da TV Cultura, ele afirma:

Quando eu fazia Liberdade Liberdade, houve um momento em que eu pensei: se eu quero agir lógica e racionalmente, o que eu devo fazer agora é entrar para o Partido Comunista. Graças a Deus não entrei!

sentido de tentar legitimar o regime em caráter democrático. Oito intelectuais e artistas foram presos por aproveitarem esse espaço para denunciar que se vivia no Brasil um regime ditatorial: Glauber Rocha, Joaquim Pedro de Andrade, Mário Carneiro (cineastas); Antônio Callado, Carlos Heitor Cony e Márcio Moreira Alves (jornalistas e escritores); Thiago Mello (poeta) e Flávio Rangel. 
Porque eu sou uma pessoa tão pouco disciplinada que eu teria ficado muito infeliz, teria brigado muito e teria saído imediatamente do Partido Comunista. Nunca fui comunista! (AUTRAN, 2002)

Ele também afirmaria sobre Liberdade Liberdade, na mesma entrevista: “Embora o espetáculo não fosse comunista, absolutamente”. Ou seja, além de se mostrar categoricamente como não comunista, Autran reconhece que o espetáculo em si também não o era, ainda que alguns participantes - leia-se, especialmente, Vianinha - o fossem. Ainda nessa entrevista, ele reforçaria o que já havia dito em entrevistas anteriores acerca de sua posição política e da importância que Liberdade Liberdade teve para despertar-lhe a consciência política:

Até então [encenar Liberdade Liberdade], eu acreditava que eu era apolítico, ignorando que uma pessoa que diz: “eu sou apolítica” está tomando uma atitude política, não é? É a atitude mais burra, é a atitude da negação, é a atitude do status quo. Então, ser apolítico é ter uma atitude muito política também e negativa.

Nara Leão, desde o show Opinião, paulatinamente deixava de ser tida como a musa da Bossa Nova para ser identificada como a cantora de protesto por excelência. Tal tomada de postura política faria dela uma das “cartas marcadas” do regime e lhe renderia até uma ofensiva do governo, que ameaçou prendê-la e processá-la. Ameaça que só não se concretizou em virtude do forte apelo de grande parte da classe artística. Tudo isso, no entanto, não a associa necessariamente ao Partido Comunista. Da mesma forma, Oscar Castro Neves (diretor musical do espetáculo), que ainda era um nome da Bossa Nova, participou de Liberdade Liberdade justamente numa viagem feita ao 
Brasil num intervalo de sua temporada nos Estados Unidos, que havia começado em 1962, após a apresentação no famoso concerto no Carnegie Hall ${ }^{13}$.

Pensando o texto da peça, o que vemos é que seu discurso, de tão aliancista, recebeu críticas de ambos os extremos, à esquerda e à direita, provocadas pela crítica à União Soviética e a ausência de crítica a Cuba e China, respectivamente. Embora exprima críticas majoritariamente a regimes autoritários de direita (nazismo, franquismo, fascismo italiano e regime militar brasileiro), recaem críticas ao comunismo soviético e àquele visto, falsamente, como o mais liberal de todos os regimes, os Estados Unidos. Esta crítica se materializa através de ironias acerca da Estátua da Liberdade, narração do fuzilamento de um desertor do exército estadunidense da Segunda Guerra, lembrança da luta pelos direitos civis.

Da mesma forma, o Terror da Revolução Francesa faz-se presente através do episódio de julgamento de Danton e da apresentação da guilhotina aos franceses. Logo em seguida, faz-se uma exaltação da Declaração dos Direitos do Homem. Trata-se de um trecho de importância crucial para a hipótese que aqui se tenta provar, já que essa declaração tem base liberal. O texto também menciona a Declaração de Independência dos Estados Unidos e o famoso discurso de Abraham Lincoln durante a Guerra Civil Americana, ambos também de tom marcadamente liberal. Já quase ao final da peça, Paulo

${ }^{13}$ Em 1962, a famosa sala de concertos Carnegie Hall, localizada em Nova Iorque, reuniu em um concerto os grandes nomes da Bossa Nova, que se tornava, então, muito conhecida nos Estados Unidos. Ainda que o concerto tenha ficado marcado por problemas técnicos, como falhas no som, ele serviu como ponto de partida na carreira internacional que muitos dos músicos que nele se apresentaram desenvolveriam a partir de então, como Tom Jobim e João Gilberto. Oscar Castro Neves participou do concerto e permanecera no exterior desde então. 
Autran lê a Declaração Universal dos Direitos do Homem, reforçando ainda mais essa temática de defesa dos direitos e das liberdades individuais.

É possível notarmos, então, que a peça, normalmente associada à resistência cultural da esquerda traz, intrinsecamente, forte marca liberal, ao passo que constroi um ambiente crítico não só aos autoritarismos como também ao liberalismo carente de liberdade dos Estados Unidos. O ápice dessa crítica se dá num trecho que reúne crítica e ironia, as duas principais marcas da peça. Apesar de longa, a citação desse trecho é exemplar:

Mas afinal, o que é liberdade? Apesar de tudo o que já se disse e de tudo o que dissemos sobre a liberdade, muitos dos senhores ainda estão naturalmente convencidos que a liberdade não existe, que é uma figura mitológica criada pela pura imaginação do homem. Mas eu lhes garanto que a liberdade existe. Não só existe, como é feita de concreto e cobre e tem cem metros de altura. A liberdade foi doada aos americanos pelos franceses em 1866 porque naquela época os franceses estavam cheios de liberdade e os americanos não tinham nenhuma. Recebendo a liberdade dos franceses, os americanos a colocaram na ilha de Bedloe, na entrada do porto de Nova York (sic). Esta é a verdade indiscutível. Até agora a liberdade não penetrou no território americano. (FERNANDES; RANGEL, op. cit.: 51)

Um pouco antes no texto, os autores se aproveitaram de um problema técnico do teatro para reforçar o que suas declarações acerca da peça diziam, incentivando o público a tomar uma posição, sem, no entanto, perder de vista a ironia. Em virtude do ranger das cadeiras, Millôr Fernandes acrescentou de última hora uma observação ao texto da peça, a ser lida por Vianinha. Ela dizia: 


\section{Cadernos de Clio, Curitiba, n. ${ }^{\circ}$ 4, 2013}

E aqui, antes de continuar este espetáculo, é necessário que façamos uma advertência a todos e a cada um. Neste momento, achamos fundamental que cada um tome uma posição definida. Sem que cada um tome uma posição definida não é possível continuarmos. É fundamental que cada um tome uma posição, seja para a esquerda, seja para a direita. Admitimos mesmo que alguns tomem uma posição neutra, fiquem de braços cruzados. Mas é preciso que cada um, uma vez tomada sua posição, fique nela! Porque senão, companheiros, as cadeiras do teatro rangem muito e ninguém ouve nada. (Idem, ibidem: 29. Grifo no original.)

Em um único episódio, o texto narra o julgamento do poeta Joseph Bordsky que, sendo poeta, trabalhava como tal nas horas vagas do emprego numa fábrica e em 1964 foi condenado a 5 anos num campo de trabalhos forçados por parasitismo social na União Soviética. O fato de a peça remeter a esse acontecimento gerou protestos e reclamações por parte da alguns membros da esquerda. A gravação do áudio da peça foi lançada em LP em 1966 e relançada em CD em 2002. A gravação foi editada e uma boa parte do áudio da encenação não consta; entre eles, o único trecho de crítica à Esquerda. Os mais extremados, à direita e à esquerda, sentiam-se ambos incomodados com o discurso da peça, que trazia em si as marcas que balizariam a resistência democrática aliancista, cujo setor e agentes principais seriam a cultura e os intelectuais, respectivamente. Alguns relatos garimpados da bibliografia são exemplares dessas insatisfações. É interessante apresentá-los a seguir.

Na biografia de Vianinha narra-se um episódio ocorrido na crítica de $O$ Globo:

Geraldo Queiróz, de O Globo, acusou o roteiro de Flávio Rangel e Millor Fernandes de deixar entrever "um aspecto propositalmente sectário, que é mostrar a liberdade de um lado, ignorando-se tudo aquilo 


\section{Cadernos de Clio, Curitiba, n. ${ }^{\circ}$ 4, 2013}

que ela representa do outro”. Segundo Queiroz, fala-se muito no período nazista ou na guerra civil espanhola, "mas nada se diz da revolução comunista de Cuba, do Muro de Berlim e de outras vezes em que a liberdade foi torpemente violada, retirando aquilo que o espetáculo defende adiante, que são os direitos civis do homem”. (MORAES, op.cit.: 196)

Aqui, o jornalista captou bem a contradição intrínseca a um projeto de base aliancista. Ao mesmo tempo em que defende os direitos civis e as liberdades individuais (reivindicações liberais), e criticam-se regimes autoritários de direita, os autores se abstêm de criticar Cuba e China e de enfatizar a crítica às supressões à liberdade na União Soviética (prática afeita de parte da esquerda). Uma consideração, porém, é importante. No caso da referência à Guerra Civil Espanhola, coube críticas a ambos os lados como mostra o trecho a seguir:

Os fascistas exerceram o terror. [...] As greves eram punidas com sentença de morte. Mulheres de milicianos tinham os seios arrancados a faca. Prisioneiros eram banhados em petróleo e depois queimados. Mas também havia atrocidades do lado republicano. Freiras foram assassinadas por recusar propostas de casamento. [...] Vários padres foram queimados. As torturas não tinham fim. (FERNANDES; RANGEL, op. cit.: 74.)

Na biografia de Flávio Rangel, há exemplos tanto à esquerda como à direita:

a peça provocaria a ira dos reacionários. Numa prévia da onda de violência contra o teatro que se tornaria moda pouco depois, Liberdade Liberdade recebeu várias ameaças. Uma delas quase se concretizou, sendo frustrada apenas pelo alerta em que já estava o grupo Opinião, que havia pedido a proteção policial. (SIQUEIRA, op.cit.: 160) 
Nesse trecho, José Rubens Siqueira se refere ao extremo ataque que seria sofrido pela peça por parte dos insatisfeitos à direita. Notícias da época dão conta de que o tumulto teria se iniciado após a manifestação de um senhor chamado Giani Pareto, industrial e comerciante, que se manifestara contra a ausência de críticas ao mundo comunista, referindo-se à peça como uma "farsa montada pelos comunistas para enganar a juventude”. ${ }^{14}$

À esquerda encontramos o seguinte exemplo:

A reação, no entanto, não veio apenas da "direita”. Um membro notório do Partido Comunista protestou, na plateia, contra a inclusão no espetáculo do atentado à liberdade sofrido pelo poeta Joseph Brodsky na União Soviética, provocando até uma reunião do comitê cultural do "partidão” para resolver a questão. Flávio e todos os envolvidos recusaram terminantemente essa "censura da esquerda”... (Idem, ibidem: 161)

O que se nota aqui é que mesmo por parte de uma ala da esquerda houve certo descontentamento com o resultado apresentado pelo Opinião, na medida em que a discussão da peça estava baseada já nos elementos constituintes do frentismo cultural determinado pelo PCB em 1958, e que seria reiterado em maio de 1965. Isso porque a opção pela aliança ampla, que abrangia também os liberais, acarretava na crítica a regimes de esquerda ao mesmo

\footnotetext{
${ }^{14}$ A acusação de Giani Pareto aparece em reportagem intitulada "Protesto contra a peça 'Liberdade Liberdade’ gerou tumulto no teatro”. O recorte de jornal com a referida reportagem consta do Acervo Nara Leão sob cuidados da Fundação Museu da Imagem e do Som do Rio de Janeiro. Não me foi possível encontrar as referências precisas de data e veículo da reportagem, contudo.
} 


\section{Cadernos de Clio, Curitiba, n. ${ }^{\circ}$ 4, 2013}

tempo em que acolhia para si a defesa de pautas historicamente embandeiradas pela ala liberal.

As questões acima apresentadas dialogam com a corrente historiográfica revisionista do regime militar que, entre outras proposições, aponta as diversas frentes da resistência civil. Apoiamo-nos na tese de resistência aliancista empreendida por comunistas e liberais e conjugamo-la com a análise de Liberdade Liberdade e a partir daí pudemos perceber que, mesmo antes do AI-2 e da resolução do Comitê Central do Partido Comunista, as bases da aliança futura já estavam lançadas. Marcos Napolitano diz que

a visão ampla e ecumênica do intelectual anti-autoritário como ator privilegiado da resistência ao regime militar recém implantado, permitiu que comunistas e liberais se unissem na defesa das "liberdades democráticas”, antes mesmo do Partido oficializar sua linha frentista e civilista de resistência, em maio de 1965. (NAPOLITANO, op. cit.: 49.)

Ou seja, tal aliança já estava, se não consolidada, pelos menos, claramente encaminhada.

O destaque e a importância de Liberdade Liberdade se dão na medida em que o teatro foi o primeiro a se levantar contra os militares. Edélcio Mostaço afirma que "Dentre todos, o teatro foi o primeiro setor a se reorganizar e propiciar uma espécie de ‘modelo’ para a arte de resistência.” (MOSTAÇO, 1982: 76). Os espetáculos encenados nos primeiros anos do regime, como Opinião (1964), Liberdade Liberdade (1965), Arena conta Zumbi (1965) e 
Cadernos de Clio, Curitiba, n. ${ }^{\circ}$ 4, 2013

Arena conta Tiradentes (1967) ${ }^{15}$, beneficiaram-se da relativa ${ }^{16}$ liberdade conferida às artes antes do Ato Institucional $\mathrm{N}^{\circ} 5$ e iniciaram a voz cultural resistente que se estenderia, com nuances, até o final do regime militar. Napolitano diz ainda:

A área teatral foi uma das mais aguerridas na fase da primeira resistência cultural contra o regime, mobilizando atores, diretores e dramaturgos na luta "contra a censura e pela liberdade de expressão". (Idem, ibidem: 62.)

Portanto, observamos que o importante papel de Liberdade Liberdade na resistência ao regime se dá não só por ser considerada a primeira peça do teatro de protesto e por ter se tornado "o carro-chefe do protesto pelo país afora” (MOSTAÇO, op. cit.: 80), mas também pelo papel central que o teatro desempenhou na resistência do frentismo cultural contra o regime militar, a censura e o cerceamento das liberdades. Napolitano acrescenta que

Em certo sentido, os artistas comunistas e seus compagnons de route foram bem sucedidos na defesa dos valores do nacional-popular, da $a$ liança de classes pela democracia, na denúncia do autoritarismo e das mazelas do regime, sem falar na política de ocupação de espaços,

${ }^{15}$ Os dois primeiros foram produzidos pelo Grupo Opinião e pelo Teatro de Arena e encenados pelo primeiro. Os dois últimos foram produzidos e encenados pelo Teatro de Arena de São Paulo.

${ }^{16}$ A liberdade para as artes é relativa, pois, ainda que somente após o AI-5 a censura e a repressão recrudescessem sua atuação sobre esta área, durante os mais de quatro anos que separam o golpe deste ato, em nenhum momento artistas atuaram livremente. O veto à Liberdade Liberdade em todo o território nacional já em 1966 e a ameaça de agressões a atores que encenavam a peça em cidades do interior do país, entre outros acontecimentos, são exemplos disso. Cf., entre outros, NAPOLITANO, 2001. 
mesmo enfrentando um duro debate na área cultural. (NAPOLITANO, op. cit.: 30. Grifo nosso.)

A resistência aliancista esteve expressa, então, nas muitas das principais vozes da resistência ao regime militar, sobretudo pelo viés da cultura, e obteve sucesso em sua atuação. Essa pesquisa mostrou que Liberdade Liberdade é paradigmática nesse sentido.

\section{REFERÊNCIAS BIBLIOGRÁFICAS}

\section{ENCICLOPÉDIA ITAÚ CULTURAL DE TEATRO.}

Disponível em www.itaucultural.org.br/teatro/ [Acesso em 23/12/2011]

GIANI, Luiz A. A música de protesto: d'O subdesenvolvido à canção do bicho e proezas de satanás (1962-1966). Dissertação de Mestrado, IFCH/Unicamp, Campinas: 1985.

MORAES, Denis de. Vianinha, cúmplice da paixão. Rio de Janeiro: Record, 2000.

NAPOLITANO, Marcos. Coração civil: arte, resistência e lutas culturais durante o regime militar. Tese de Livre Docência em História do Brasil Independente, Universidade de São Paulo, 2011.

cultural na MPB (1959 - 1969). São Paulo: Annablume: FAPESP, 2001.

PATRIOTA, Rosângela. Vianinha: um dramaturgo no coração de seu tempo. São Paulo: Hucitec, 1999.

SCHWARZ, Roberto. Cultura e política: 1964 - 1969. In: O pai de família e outros estudos. Rio de Janeiro: Paz e Terra, 1978.

SIQUEIRA, José Rubens. Viver de teatro: uma biografia de Flávio Rangel. São Paulo: Nova Alexandria, 1995. 
Cadernos de Clio, Curitiba, n. ${ }^{\circ}$ 4, 2013

\section{FONTES}

AUTRAN, Paulo. Roda Viva. São Paulo: TV Cultura, 2002. Disponível em http://www.youtube.com/watch?v=2Ype44mJo3U [Acesso em 30/07/2012]

LIBERDADE LIBERDADE ou Seleção de textos de Flávio Rangel e Millôr Fernandes. Processo de Censura. Peças Teatrais. Teatro. Divisão de Censura de Divisões Públicas. Arquivo Nacional do Distrito Federal.

MICHALSKI, Yan. Liberdade Liberdade (I). Jornal do Brasil, Rio de Janeiro, 27 abril 1965.

FERNANDES, Millôr; RANGEL, Flávio. Liberdade Liberdade. Porto Alegre: L\&PM, 1997.

ONIS, Juan de. New plays chide brazilian regime; Productions Temper Protest With Humor and Music. The New York Times, Nova Iorque, 25 abril 1965. 